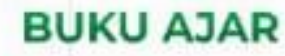

\section{PARIWISATA} BERBASIS MASYARAKAT

KONSEP DAN PRAKTIK

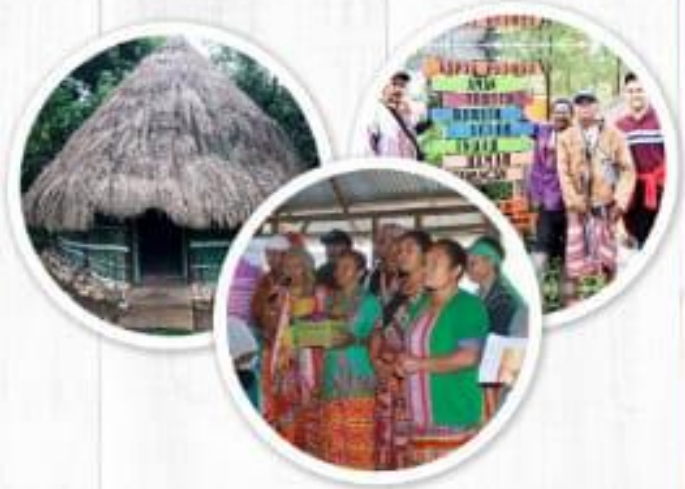

Konsep pariwisata berbasis masyarakat beberapa kali didefinisikan sebagai sebuah jenis pariwisata yang mengutamakan kontrol masyarakat lokal dalam pengelolaan dan pengembangan sebuah destinasi (Denman 2001; dalam Putra 2015). Masyarakat lokal dalam konsep pariwisata berbasis masyarakat memiliki kesadaran untuk berpartisipasi secara aktif dalam pembangunan kepariwisataan di wilayahnya melalui kelangsungan budaya, sosial, dan lingkungan (Prabawati:2013). Berdasarkan definisi tersebut, maka setidaknya terdapat dua kata kunci yang melekat dengan konsep pariwisata berbasis masyarakat yaitu mengenai pemberdayaan masyarakat dan partisipasi masyarakat. Buku ajar ini berupaya untuk menggambarkan penerapan mata kuliah pariwisata berbasis masyarakat dalam tataran konsep teoritis dan juga praktik dilapangan terutama dalam mendukung pengembangan desa wisata di Indonesia.
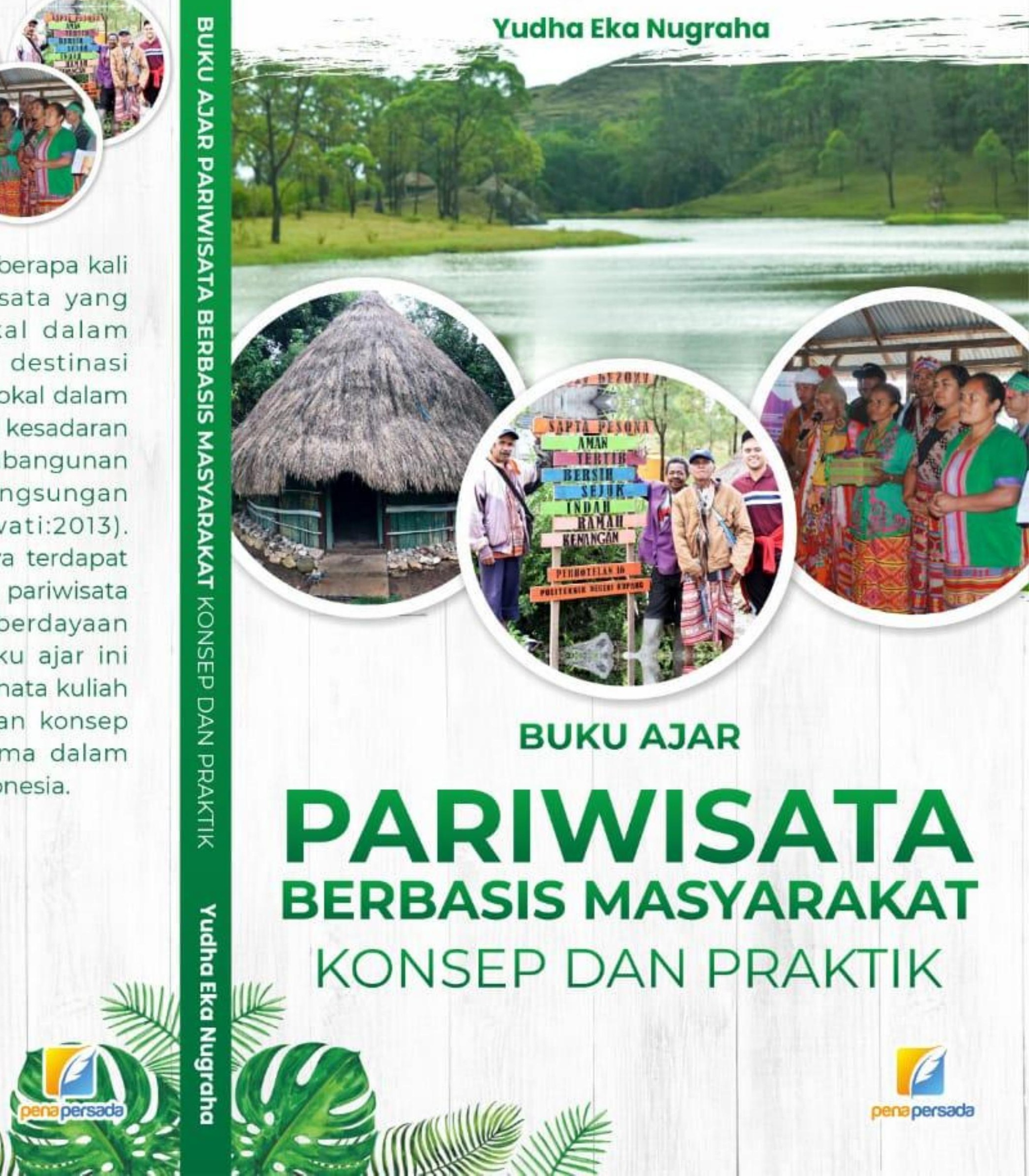


\title{
BUKU AJAR \\ Pariwisata Berbasis Masyarakat \\ Konsep dan Praktik
}

\author{
Yudha Eka Nugraha
}

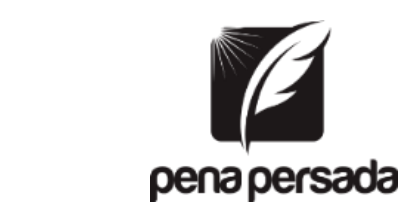

PENERBIT CV. PENA PERSADA 


\title{
BUKU AJAR \\ Pariwisata Berbasis Masyarakat \\ Konsep dan Praktik
}

\section{Penulis:}

Yudha Eka Nugraha

ISBN : 978-623-315-223-5

Design Cover :

Retnani Nur Briliant

\section{Layout :}

Eka Safitry

\section{Penerbit CV. Pena Persada \\ Redaksi :}

Jl. Gerilya No. 292 Purwokerto Selatan, Kab. Banyumas

$$
\text { Jawa Tengah }
$$

Email : penerbit.penapersada@gmail.com

Website : penapersada.com Phone : (0281) 7771388

\section{Anggota IKAPI}

\author{
All right reserved \\ Cetakan pertama : 2021
}

Hak Cipta dilindungi oleh undang-undang. Dilarang memperbanyak karya tulis ini dalam bentuk apapun tanpa izin penerbit 


\section{Kata Pengantar}

Puji Syukur kehadirat Tuhan Yang Maha Esa, karena berkat rahmat dan kuasa-Nya buku ajar mata kuliah Pariwisata Berbasis Masyarakat Konsep dan Praktik ini bisa terselesaikan dengan baik. Buku ajar ini akan membahas mengenai materi yang berkaitan dengan konsep pariwisata berbasis masyarakat dalam kajian konsep peran, bentuk, maupun partisipasi masyarakat untuk tujuan mengembangkan potensi wisata yang ada di sebuah kawasan/desa/wilayah. Selain itu konsep pariwisata berbasis masyarakat yang ada akan dihubungkan dengan penerapan praktis dalam pengembangan Desa Wisata yang akan diuraikan lebih lanjut dalam buku ajar ini. Ruang lingkup materi dalam buku ini pada contoh kasus penerapan pariwisata berbasis masyarakat dalam pembangunan desa wisata di Provinsi Nusa Tenggara Timur. 


\section{DAFTAR ISI}

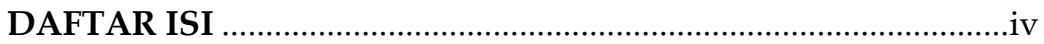

BAB 1 KONSEP PARIWISATA BERBASIS MASYARAKAT ......1

BAB 2 MODAL SOSIAL DALAM PEMBANGUNAN

PARIWISATA BERBASIS MASYARAKAT ……..........................

BAB 3 PEMBERDAYAAN MASYARAKAT DALAM

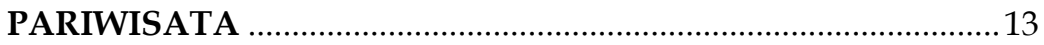

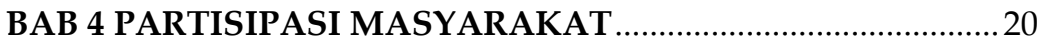

BAB 5 PRODUK PARIWISATA BERBASIS MASYARAKAT ...28

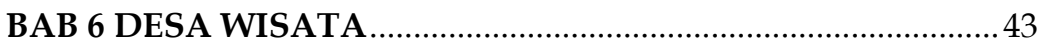

BAB 7 PEMANTAUAN PARIWISATA BERBASIS

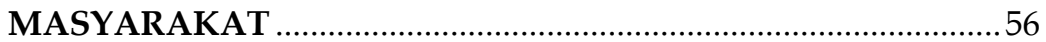

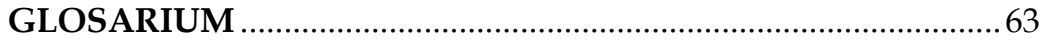

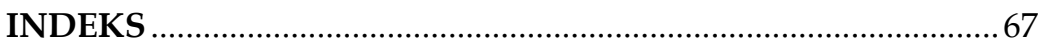

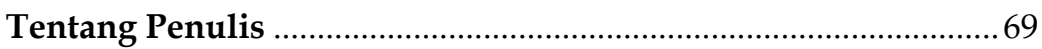




\section{BAB 1 \\ KONSEP PARIWISATA BERBASIS \\ MASYARAKAT}

\subsection{Tujuan Pembelajaran}

Setelah mempelajari bab ini, mahasiswa akan memiliki kemampuan:

1. Mampu memahami dan mengembangkan definisi operasional mengenai konsep pariwisata berbasis masyarakat.

2. Mampu memahami isu-isu pengembangan pariwisata berbasis masyarakat

3. Mampu memahami tantangan dan hambatan dalam penyelenggaraan pariwisata berbasis masyarakat.

\subsection{Konsep Pariwisata Berbasis Masyarakat}

Terminologi Community Based Tourism (Pariwisata Berbasis Masyarakat) muncul sejak tahun 1990-an (Putra, 2015). Lebih tepatnya, pada tahun 1995, Kementerian Pariwisata Indonesia memperkenalkan istilah Pariwisata Berbasis Masyarakat ke khalayak sehingga istilah ini semakin terkenal hingga tahun 2017 jenis pariwisata ini diklaim sebagai salah satu katalisator pembangunan Indonesia.

Konsep pariwisata berbasis masyarakat beberapa kali didefinisikan sebagai sebuah jenis pariwisata yang mengutamakan kontrol masyarakat lokal dalam pengelolaan dan pengembangan sebuah destinasi (Denman 2001; dalam Putra 2015). Masyarakat lokal dalam konsep pariwisata berbasis masyarakat memiliki kesadaran untuk berpartisipasi secara aktif dalam pembangunan kepariwisataan di wilayahnya melalui kelangsungan budaya, sosial, dan lingkungan (Prabawati:2013). Berdasarkan definisi tersebut, maka setidaknya terdapat dua kata kunci yang melekat 
dengan konsep pariwisata berbasis masyarakat yaitu mengenai pemberdayaan masyarakat dan partisipasi masyarakat.

Pemberdayaan dalam pariwisata berbasis masyarakat merupakan sebuah kegiatan berproses yang bukan hanya untuk meningkatkan peluang masyarakat tertinggal dalam mengembangkan perekonomian saja (Sunaryo, 2013). Namun, (Prijono,1996 dalam Theresia, 2015) menyebutkan bahwa pemberdayaan adalah sebuah proses memberikan stimulus berupa pelatihan-pelatihan kepada warga agar menjadi lebih baik, termotivasi, terdorong, berdaya, memiliki kemampuan dan kesadaran dalam menentukan tujuan hidupnya. Keterkaitan antara pariwisata berbasis masyarakat dan pemberdayaan terdapat pada kesadaran masyarakat untuk bangkit dan berusaha mengelola segala aspek yang dimiliki oleh masyarakat sebagai modal sosial beserta potensi alam dan budaya yang dimiliki dalam pembangunan kepariwisataan sebuah destinasi.

Kaitan pariwisata berbasis masyarakat yang kedua yakni mengenai partisipasi masyarakat (Timothy dan Boyd 2003) yang menyebutkan bahwa keikutsertaan masyarakat (partisipasi) dalam sebuah kegiatan pariwisata berbasis masyarakat dapat ditunjukkan dengan dua cara yaitu: keterlibatan masyarakat dalam mengambil keputusan dan keadilan dalam pembagian manfaat pariwisata. Pertama, partisipasi dalam mengambil keputusan memiliki arti bahwa masyarakat mempunyai kesempatan untuk menyampaikan pendapat, harapan, bahkan kekhawatiran atau rasa tidak setuju dalam suatu pembangunan kepariwisataan. Partisipasi masyarakat ini bermanfaat untuk menghasilkan keputusan dan input dalam proses perencanaan pariwisata. Kedua, keadilan dalam pembagian manfaat pariwisata terkait dengan hak masyarakat yang semestinya memiliki kesempatan yang sama untuk memperoleh keuntungan dalam pembangunan pariwisata yang telah dilakukan di wilayahnya. Manfaat ini bisa berupa finansial secara langsung, peluang pekerjaan, 
kesempatan berusaha, mendapatkan pelatihan kepariwisataan, dan mendapatkan pendidikan agar sadar wisata (Timothy, 1999).

Isu pengembangan pariwisata pariwisata berbasis masyarakat terkait dengan perhatian badan atau kelompok internasional dalam beberapa tahun terakhir, Contohnya dalam (Putra, 2015) kelompok negara-negara yang tergabung dalam APEC (Asia Pacific Economic Cooperation) memberikan penekanan pentingnya CBT sebagai alat pembangunan untuk mewujudkan pembangunan berkelanjutan. Korelasi antara pariwisata berbasis masyarakat dan pembangunan berkelanjutan menunjukkan bahwa jika masyarakat memiliki kesadaran dan berdaya serta ikut berpartisipasi dalam pengelolaan destinasi maka kondisi yang ideal akan tercapai. Kondisi ideal ini dinyatakan oleh UNWTO karena pembangunan berkelanjutan dimulai dari level individu, komunitas, atau masyarakat (dari bawah). Kembali lagi, hal ini terjadi karena pariwisata berbasis masyarakat melibatkan masyarakat lokal dalam proses pengambilan keputusan sesuai prioritas destinasi yang sedang dikembangkan. Peluang ini membuat seluruh pihak masyarakat dalam suatu wilayah memiliki keterlibatan dan tanggung jawab yang sama dalam sebuah sistem pariwisata yang akan mendatangkan keuntungan ekonomi, kelangsungan sosial budaya, dan keberlanjutan lingkungan destinasi.

Walaupun pariwisata berbasis masyarakat dikenal sebagai katalisator pembangunan sekaligus salah satu pendekatan pembangunan berkelanjutan, tetap ada tantangan dan hambatan dalam menerapkan pariwisata berbasis masyarakat yang ideal. Tantangan ini (Putra 2016) muncul dari berbagai kritik terhadap pembangunan pariwisata berbasis masyarakat, yang pertama adalah ketidakberhasilan pariwisata berbasis masyarakat dalam mengentaskan kemiskinan. Kritik kedua pariwisata berbasis masyarakat adalah penyebab terjadinya museumizing ethnic people (Burns 2004:31) yang berarti bahwa masyarakat asli atau lokal 
(indigenous people) digiring untuk membekukan tradisi budaya sebagai daya tarik wisata demi memuaskan harapan wisatawan karena harus memenuhi permintaan wisatawan yang datang untuk menemukan sesuatu yang baru, dalam hal ini budaya masyarakat lokal. Ketiga dan yang paling sering ditemukan adalah pariwisata berbasis masyarakat bisa menjadi kegagalan karena lembaga pemberi dana untuk sekali jalan saja, masyarakat lokal tidak siap jika pendampingan yang diberikan oleh lembaga donor diberhentikan sehingga kemampuan masyarakat dalam mengelola destinasi wisata belum kuat. Seperti yang disampaikan dalam (Moscardo, 2008) dimana ketika lembaga donor berhenti memberikan pendampingan pada proyek pariwisata berbasis masyarakat maka proyek CBT tersebut lesu, layu, dan tidak berlanjut.

Tantangan keempat dalam pembangunan pariwisata berbasis masyarakat adalah kurang menariknya produk wisata yang ditawarkan kepada wisatawan. Hal ini berdampak pada minat wisatawan yang rendah untuk melakukan kegiatan wisata di destinasi tersebut. Hal ini terkait dengan lemahnya pemberdayaan juga partisipasi masyarakat di destinasi wisata (Putra, 2015). Selama proses perencanaan pariwisata berbasis masyarakat tidak benarbenar dilakukan sepenuhnya oleh keputusan masyarakat lokal sehingga banyak campur tangan dari luar seperti konsultan, staff pemerintahan, atau perwakilan lembaga donor yang memiliki pengetahuan dan pengalaman yang lebih tinggi sehingga mengecilkan porsi partisipasi masyarakat lokal.

Tantangan dan hambatan tersebut muncul diantaranya terjadi karena sebab-sebab berikut diantaranya; pertama, dana yang tersedia dalam mengelola destinasi wisata berbasis masyarakat tidak memadai. Kedua, penerapan pariwisata berbasis masyarakat tidak bisa dilakukan dalam jangka pendek, masyarakat lokal memerlukan waktu untuk menyesuaikan diri bekerja bersama untuk mengambil 
keputusan sehingga proses yang panjang ini seringkali membuat peluang yang muncul hilang. Ketiga, masyarakat lokal mengalami kesulitan mencari perwakilan yang memiliki komitmen tinggi dalam menerapkan pendekatan CBT, keempat terdapatnya kepentingan politik yang ditunjukkan masyarakat, dan kelima adalah mengenai perbedaan pendapat dan ketidaksesuaian persepsi atas pariwisata antar masyarakat (Hall, 2000; Timothy dan Tosun,2003; dalam Putra, 2015).

\subsection{Pertanyaan}

1. Jelaskan mengenai dua hal yang melekat dalam istilah pariwisata berbasis masyarakat!

2. Jelaskan kaitan pemberdayaan masyarakat dan pariwisata berbasis masyarakat!

3. Jelaskan kaitan partisipasi masyarakat dan pariwisata berbasis masyarakat!

4. Apa saja isu yang terkait dengan pengembangan pariwisata berbasis masyarakat?

5. Sebutkan kemungkinan tantangan dan hambatan yang dihadapi bila memutuskan untuk melakukan pengembangan pariwisata berbasis masyarakat! 


\section{Daftar Pustaka}

Burns, P. M. (2004). Tourism planning: A third way?. Annals of Tourism Research, 31(1), 24-43.

Putra, I. N. D. (Ed.). (2015). Pariwisata berbasis masyarakat model Bali. Buku Arti.

Prabawati, H. J. K. (2013). Faktor-Faktor keberhasilan community based tourism dalam pengembangan desa wisata (studi kasus: PNPM mandiri pariwisata di dataran tinggi Dieng). Tugas Akhir Tidak Diterbitkan, Jurusan Perencanaan Wilayah dan Kota, Fakultas Teknik Universitas Diponegoro, Semarang.

Sunaryo, B. (2013). Kebijakan pembangunan destinasi pariwisata: konsep dan aplikasinya di Indonesia (No.1). Penerbit Gava Media Kebijakan Pembangunan Destinasi Pariwisata: Konsep dan Aplikasinya di Indonesia.

Theresia, A., Andini, K. S., Nugraha, P. G., \& Mardikanto, T. (2014). Pembangunan berbasis masyarakat: acuan bagi praktisi, akademisi, dan pemerhati pengembangan masyarakat. Penerbit Alfabeta.

Timothy, Dallen J., 1999, Partcipatory Planning; A View of Tourism in Indonesia, Annals of Tourism Research, 26: 371-391

Timothy, Dallen J. dan Boyd, Stephen W., 2003, Heritage Tourism, Pearson Education, England

Timothy, D. J., \& Tosun, C. (2003). Appropriate planning for tourism in destination communities: Participation, incremental growth and collaboration. Tourism in destination communities, 181-204. 


\section{BAB 2 \\ MODAL SOSIAL DALAM \\ PEMBANGUNAN PARIWISATA BERBASIS MASYARAKAT}

\subsection{Tujuan Pembelajaran}

Setelah mempelajari bab ini, mahasiswa akan memiliki kemampuan:

1. Mampu memahami arti penting modal sosial dalam perencanaan pariwisata berbasis masyarakat

2. Mampu memahami pengertian modal social dalam perencanaan pariwisata berbasis masyarakat

3. Mampu memahami unsur dan parameter modal social dalam perencanaan pariwisata berbasis masyarakat

\subsection{Arti Penting Modal Sosial dalam Perencanaan Pariwisata Berbasis Masyarakat}

Berbicara mengenai pembangunan kepariwisataan berbasis masyarakat, tentu kita perlu mempelajari komponenkomponen penyusun pembangunan kepariwisataan salah satu yang penting adalah modal sosial (Bisena, 2011 dalam Theresia 2014). Konsep "modal sosial" sudah cukup lama diperkenalkan lewat tulisan Jane Jacobs (1961) dan James S. Coleman (1988). Modal sosial merupakan sebuah unsur hubungan sosial yang terdiri dari beberapa aspek misalnya: hubungan sosial (pengetahuan lokal, tingkah laku, kearifan, kerjasama, dan kesetiaan), institusi sosial (jaringan, perkumpulan, dan kepemimpinan sosial), dan nilai-nilai yang universal (norma simpati, norma kejujuran, norma toleransi, dan norma kepercayaan) yang diterapkan dalam kehidupan sehari-hari secara tepat guna melahirkan kontrak sosial, peran serta masyarakat, tanggung jawab sosial, dan kemandirian. 
Menurut Theresia (2014), menyebutkan bahwa modal sosial adalah masyarakat yang ada di dalamnya. Sesuai dengan tema dalam buku ini, masyarakat yang dimaksud adalah masyarakat yang berada dalam kawasan destinasi wisata.

Pada dasarnya, masyarakat memiliki keinginan yang baik untuk berubah. Masyarakat memiliki kekuatan untuk berubah melalui wujud pembangunan dan perubahan kearah yang lebih baik. Masyarakat yang berkeinginan kuat ini adalah modal dasar bagi pembangunan negara (Theresia, 2014). Sebab, masyarakat ini memiliki pandangan dan pola pikir yang terbuka sehingga mampu bekerjasama sekaligus menerapkan ilmu-ilmu baru yang mendukung perkembangan suatu destinasi wisata. Lebih lanjut, peran masyarakat dalam pembangunan tidak hanya untuk menerapkan pandangan dan pola pikir yang terbuka, namun juga untuk memelihara hasil dari pembangunan yang telah dilakukan dalam konteks pengembangan kepariwisataan. Sehingga terlihat bahwa kesadaran masyarakat dalam proses perencanaan dan pembangunan akan berhasil dan terpelihara jika masyarakat memiliki budaya tersebut, sebagai modal sosial pembangunan.

Terdapat enam hal yang membuat modal sosial itu penting menurut (Mawarni, 2000). Pertama, memudahkan anggota komunitas dengan memberi akses informasi yang dibutuhkan. Kedua, modal sosial merupakan media pendukung kekuasaan dalam komunitas. Ketiga, membangkitkan solidaritas antar sesama anggota dalam sistem masyarakat. Keempat, mempermudah mobilisasi sumber daya yang dimiliki oleh masyarakat lokal. Kelima, memiliki tujuan bersama yang jelas sehingga peluang tujuan tercapai terbuka lebar. Keenam, membentuk perilaku kebersamaan dan kebiasaan berorganisasi bagi masyarakat lokal. Perencanaan pariwisata berbasis masyarakat merupakan tahapan awal perubahan masyarakat dalam mengelola kawasan destinasi wisata sesuai dengan kekuatan modal sosial yang dimiliki. Tujuan utama dari perencanaan 
pariwisata berbasis masyarakat melalui modal sosial adalah terciptanya percepatan pembangunan terutama dalam bidang kepariwisataan di Indonesia.

Modal sosial dalam perencanaan pariwisata berbasis masyarakat memiliki unsur-unsur pokok. Hal-hal berikut melatarbelakangi munculnya istilah modal sosial dalam perencanaan pariwisata berbasis masyarakat. Menurut (Hasbullah, 2006), terdapat enam hal unsur pokok modal sosial yaitu; pertama, partisipasi dalam suatu jaringan. Partisipasi dalam kepariwisataan adalah kemampuan masyarakat lokal melibatkan diri dalam jaringan hubungan sosial misalnya dalam perencanaan pariwisata setempat. Partisipasi masyarakat dalam perencanaan pariwisata akan membuat sinergi kekuatan baik langsung maupun tidak langsung, dampaknya jaringan sosial akan semakin kuat dan tujuan pembangunan akan lebih cepat tercapai. Kedua, adanya hubungan timbal balik (reciprocity), adanya keikutsertaan individu atau masyarakat dalam jaringan hubungan sosial akan menimbulkan suatu pertukaran diantara individu yang saling berinteraksi. Pertukaran yang tercipta dari hasil interaksi merupakan hubungan timbal balik. Hubungan timbal balik antar anggota masyarakat lokal diasumsikan sebagai hubungan timbal balik yang saling melengkapi dan saling mendukung. Sehingga, pada saat terdapat anggota kelompok yang sedang mengalami masalah, hubungan timbal balik ini menjadi modal yang kuat untuk masyarakat lokal untuk dapat melanjutkan hidup dan perencanaan Bersama masyarakat. Ketiga, rasa percaya (trust) yang berarti bahwa individu dalam masyarakat lokal meyakini bahwa individu lain akan bertindak sesuatu seperti yang diharapkan dalam suatu pola jaringan hubungan sosial. Rasa percaya tidak muncul secara tiba-tiba, keyakinan ini harus dipupuk terus menerus dan berlangsung alamiah.

Keempat, norma sosial yang berarti seperangkat aturan yang tertulis maupun tidak tertulis dan telah disepakati oleh setiap anggota dalam sebuah komunitas masyarakat lokal 
yang bertujuan untuk memberikan batasan berperilaku bagi setiap anggota dalam komunitas. Norma sosial itu bersifat kolektif, artinya bahwa norma sosial yang dipatuhi dalam suatu komunitas lokal bisa jadi diakui sebagai hal yang sama dengan norma sosial yang berlaku di komunitas masyarakat lainnya tetapi tidak semua bentuk penerapan atau tindakannya bisa digeneralisir. Norma sosial memiliki konsekuensi yang ditaati bersama masyarakat lokal. Suatu pelanggaran atau ketidaktaatan terhadap norma sosial mengakibatkan individu dikenai sanksi sesuai kesepakatan masyarakat lokal. Bentuknya bisa berupa sanksi sosial dalam bentuk sikap yang ditunjukkan sehari-hari, penolakan terhadap yang melanggar, dan tindakan tidak melibatkan yang melanggar dalam kegiatan perencanaan pariwisata. Kelima, nilai-nilai yaitu suatu ide yang dianggap benar oleh anggota masyarakat lokal dan diwariskan secara turun temurun. Contoh nilai-nilai yang dianggap benar misalnya: nilai prestatif, nilai harmoni dan keselarasan, nilai kompetisi, dan nilai etos kerja (kerja keras). Nilai-nilai yang dipatuhi bersama ini berperan sebagai sebuah moto penggerak bagi anggota komunitas dalam sebuah masyarakat lokal.

Misalnya nilai kesetiakawanan dengan melakukan kegiatan perencanaan bersama-sama. Unsur keenam yaitu tindakan proaktif, keinginan kuat dari anggota masyarakat lokal untuk terlibat dalam melakukan tindakan perubahan bagi kelompoknya. Tindakan proaktif tidak terbatas pada partisipasi dalam arti kehadiran dan menjadi bagian dalam kelompok masyarakat lokal. Lebih dari itu, tindakan proaktif dalam modal sosial ditunjukkan berupa kontribusi nyata dalam berbagai bentuk aksi kegiatan. Tindakan proaktif lebih lanjut dilakukan untuk meningkatkan hubungan kekerabatan, meningkatkan intensitas antar masyarakat lokal, dan membagi energi positif di antara anggota masyarakat lokal.

Konsep modal sosial memiliki kelemahan, dalam (Theresia, 2014) salah satu kelemahan utama dalam konsep modal sosial adalah kurangnya metode untuk mengukur 
sejauh mana penerapan modal sosial pada masyarakat lokal. Sehingga hal ini membuat modal sosial sulit diukur terutama dikaitkan dengan pengukuran faktor dampak terhadap beberapa variable lainnya. Terkait dengan kelemahan tadi, Ridell, 1997 menyatakan bahwa ada tiga parameter modal sosial yaitu kepercayaan (trust), norma-norma (norms), dan jaringan (networks). Bila dihubungkan dengan materi mengenai unsur-unsur dalam modal sosial, maka ketiga parameter tersebut dapat dijadikan parameter yang dapat mengukur sejauh mana faktor atau dampak modal sosial dalam masyarakat lokal bisa diukur terutama dengan kontribusinya dalam keberhasilan proses perencanaan pariwisata berbasis masyarakat.

\subsection{Pertanyaan}

1. Jelaskan pengertian modal sosial menurut ahli!

2. Sebutkan dan jelaskan unsur-unsur pokok yang melatarbelakangi modal sosial!

3. Sebutkan dan jelaskan parameter yang dapat digunakan untuk mengukur dampak dari modal sosial!

4. Mengapa pendekatan modal sosial memiliki suatu kelemahan?

5. Sebutkan dan jelaskan siapakah yang dimaksud modal sosial dalam suatu kasus pengembangan destinasi pariwisata berbasis masyarakat? 


\section{Daftar Pustaka}

Coleman, J. S. (1988). Social capital in the creation of human capital. American journal of sociology, 94, S95-S120.

Hasbullah, J. (2006). Social Capital: Menuju Keunggulan Budaya Manusia Indonesia. MR-United Press.

Mawarni, A. (2010). Pentingnya Modal Sosial Dalam Pembangunan Pasca Bencana, diakses

http://www.pspk.ugm.ac.id/artikel-terbaru/81pentingnya-modal-sosial-dalam pembangunan-pascabencana.html, diakses 28 April 2020

Riddell, M. (1997). Bringing back balance: the role of social capital in public policy. Social Capital and Policy Development. Wellington, NZ: Institute of Policy Studies, 13-33.

Theresia, A., Andini, K. S., Nugraha, P. G., \& Mardikanto, T. (2014). Pembangunan berbasis masyarakat: acuan bagi praktisi, akademisi, dan pemerhati pengembangan masyarakat. Penerbit Alfabeta. 


\section{BAB 3 \\ PEMBERDAYAAN MASYARAKAT DALAM PARIWISATA}

\subsection{Tujuan Pembelajaran}

Setelah mempelajari bab ini, mahasiswa akan memiliki kemampuan:

1. Mampu memahami pengertian pemberdayaan masyarakat dalam kepariwisataan.

2. Mampu memahami pokok-pokok pemberdayaan masyarakat dalam kepariwisataan.

3. Mampu memahami ruang lingkup kegiatan pemberdayaan masyarakat dalam pembangunan pariwisata berbasis masyarakat.

\subsection{Pariwisata dan Pemberdayaan Masyarakat}

Terdapat korelasi antara pemberdayaan masyarakat dan bidang kepariwisataan. Dalam bab ini akan dijelaskan mengenai korelasi kedua istilah tersebut. Penelitian mengenai definisi pemberdayaan masyarakat telah dijelaskan menurut (Theresia, 2014) yang berarti bahwa memberdayakan, memampukan, dan memandirikan masyarakat. Lebih lanjut (Sumodiningrat, 1999) menyatakan bahwa pemberdayaan masyarakat merupakan upaya untuk memandirikan masyarakat lewat pemanfaatan potensi kemampuan yang mereka miliki. Berdasarkan pengertian tersebut, pemberdayaan masyarakat dalam buku ini menyimpulkan bahwa pemberdayaan merupakan sebuah usaha untuk meningkatkan kualitas hidup, harkat, serta martabat suatu kelompok dalam masyarakat dari kondisi saat ini yang tidak berdaya karena kemiskinan dan keterbelakangan menjadi lebih baik. Dalam proses pemberdayaan masyarakat, pembangunan pariwisata diarahkan pada pengembangan 
sumberdaya manusia yang ada di perdesaan, penciptaan peluang kerja, yang sesuai dengan kebutuhan masyarakat desa. Masyarakat dimampukan secara mandiri untuk mengelola destinasi wisata agar dapat menentukan jenis usaha, kondisi wilayah, menciptakan lembaga pendukung kepariwisataan, dan sistem pelayanan kepada wisatawan dalam pembangunan pariwisata berbasis masyarakat.

Terdapat beberapa pokok rangkaian yang dapat menjelaskan pemberdayaan masyarakat dalam pembangunan pariwisata berbasis masyarakat. Sebagai sebuah rangkaian aktivitas, proses pemberdayaan mengutamakan upaya-upaya untuk memperkuat dan mengoptimalkan kunggulan yang dimiliki oleh sebuah komunitas berdasarkan sumber daya yang ada pada kemampuan komunitas masyarakat yang marginal, lemah baik secara ekonomi maupun sosial, dan individu yang lemah akibat menghadapi masalah kemiskinan. Kegiatan pemberdayaan masyarakat merupakan suatu proses dimana masyarakat lokal terutama kelompok rentan seperti individu yang mengalami masalah kemiskinan, kelompok terabaikan, dan kelompok perempuan yang terabaikan yang perlu mendapatkan dukungan agar termotivasi untuk meningkatkan kualitas hidupnya secara mandiri dalam kehidupan. Salah satunya melalui kegiatan pemberdayaan dalam bidang pariwisata yang berbasis masyarakat.

Sejatinya dalam proses pemberdayaan terdapat seorang pendamping. Pendamping berperan sebagai fasilitator untuk mendampingi proses pemberdayaan masyarakat. Pendamping dalam konteks pemberdayaan masyarakat bisa datang dari berbagai pihak seperti dalam konsep yang baru diperkenalkan oleh Menteri Pariwisata, (Arief Yahya dalam Yuningsih, 2019) terdapat model pentahelix pariwisata yaitu Akademisi, Bisnis, Komunitas, Pemerintahan, dan Media Masa. Namun, bukan berarti munculnya pendamping membuat peran masyarakat lokal menjadi tidak dominan, pendamping membantu agar masyarakat mampu mengelola 
dan menemukan solusi yang tepat untuk masalah yang dihadapi. Masyarakat lokal tetap sebagai aktor dalam pemberdayaan masyarakat untuk pembangunan pariwisata berbasis masyarakat.

Pokok pemberdayaan masyarakat yang pertama adalah pemberdayaan sebagai proses perubahan. Proses perubahan dalam pemberdayaan masyarakat didefinisikan oleh (Lippit,dkk 1985 dalam Theresia 2014) terjadi karena dua hal. Hal pertama adalah adanya keinginan manusia untuk selalu memenuhi kebutuhan yang terus berubah dan keinginan manusia untuk memecahkan masalah yang dihadapi dengan mengelola sumber daya dan lingkungan disekelilingnya menggunakan pengetahuan dan teknologi yang dikuasainya. Kedua, ditemukannya inovasi yang memberikan peluang bagi masyarakat untuk menumbuhkan aspirasi untuk memperbaiki kesejahteraan hidup tanpa harus mengganggu lingkungan asli. Kedua alasan ini menjadi penyebab dasar manusia ingin melakukan upaya-upaya perubahan agar tidak selamanya mengalami ketertinggalan atau keterbelakangan. Dalam pokok ini, peran pendampingan perlu dilakukan salah satunya oleh akademisi untuk melakukan fungsi edukasi kepada masyarakat agar masyarakat memiliki motivasi yang tinggi untuk melakukan perubahan dari dalam dirinya.

Pokok pemberdayaan masyarakat yang kedua adalah pemberdayaan sebagai proses pembelajaran. Perubahan terencana dalam pemberdayaan masyarakat lokal dapat dilakukan dengan proses pembelajaran yaitu: pemaksaan, ancaman, bujukan atau pendidikan. Proses pembelajaran dalam pemberdayaan masyarakat melalui pemaksaan, ancaman, ataupun bujukkan memang cukup efektif dalam upaya merubah kondisi masyarakat lokal, hanya saja perubahan tersebut menciptakan ketergantungan dan tidak berlangsung lama. Misalnya saja dengan menggunakan pembelajaran bujukkan, masyarakat lokal diberikan insentif dalam melakukan perubahan. Hal ini membuat masyarakat lokal menjadi tergantung dalam melakukan perubahan. 